\title{
Detection of Laem-Singh virus (LSNV) in cultured Penaeus monodon from India
}

\author{
B. K. Prakasha1 ${ }^{1}$, Raju P. Ramakrishna ${ }^{2}$, Indrani Karunasagar ${ }^{1, *}$, Iddya Karunasagar ${ }^{1}$ \\ ${ }^{1}$ Department of Fishery Microbiology, Karnataka Veterinary, Animal and Fisheries Sciences University, College of Fisheries, \\ Mangalore 575 002, India \\ ${ }^{2}$ State Institute of Fisheries Technology, Kakinada, Andhra Pradesh 533 002, India
}

\begin{abstract}
Viral diseases have become a major constraint on the growth of shrimp aquaculture in India. During a study of new diseases in cultured shrimp Penaeus monodon, diseased samples randomly collected from the southwestern and southeastern coasts of India were analyzed for white spot syndrome virus (WSSV), monodon baculovirus (MBV), and hepatopancreatic parvovirus (HPV) by nested PCR, and for Laem-Singh virus (LSNV) by reverse transcription PCR (RT-PCR). Of the 56 samples analyzed, 3 were positive for LSNV. These samples had signs of loose shell syndrome (LSS). Of the 3 samples that tested positive for LSNV, 2 were also positive for WSSV and MBV, and of these 2 samples, 1 was also positive for HPV. This is the first reported presence of LSNV in cultured shrimp in India.
\end{abstract}

KEY WORDS: Laem-Singh virus $\cdot$ Loose shell syndrome $\cdot$ Penaeus monodon $\cdot$ Reverse transcription PCR (RT-PCR)

Resale or republication not permitted without written consent of the publisher

\section{INTRODUCTION}

The sustainability and economic success of the shrimp culture industry have been adversely affected by viral diseases. In the presence of predisposing environmental conditions, viruses cause disease outbreaks resulting in massive losses to the industry. Intensive shrimp cultivation, inadequate sanitation, poor pond management and irresponsible movement of broodstock and larvae have exacerbated the disease incidence and enhanced its spread. With expansion of the industry, the number of viral pathogens of penaeid shrimp has also increased, reaching a new high of 20, as compared to only 6 in 1988 (Lightner 1988, 1993, 1996).

Among all known viruses of shrimp, white spot syndrome virus (WSSV) is the most prevalent and is considered to be pandemic, affecting most countries that culture shrimp. In addition to single viral pathogens, multiple viral infections of cultured shrimps have also been reported. These include triple infections with yellow head virus (YHV), hepatopancreatic parvovirus (HPV) and monodon baculovirus (MBV) in Penaeus monodon (Chantanachookin et al. 1993), HPV, MBV and WSSV in post larvae (Manivannan et al. 2002) and, recently, MBV, HPV and WSSV in adult prawns (Umesha et al. 2006).

Recently, several new diseases of unknown or obscure etiology have been reported in the shrimp culture industry. These include swollen hindgut syndrome (SHG) (Lavilla-Pitogo et al. 2002), monodon slow growth syndrome (MSGS) (Chayaburakul et al. 2004) and loose shell syndrome (Mayavu et al. 2003). MSGS was first observed in cultured Penaeus monodon in Thailand, and in the absence of known viral pathogens, the causative agent was designated as monodon slow growth agent (MSGA) (Chayaburakul et al. 2004). Later investigations revealed the presence of a virus called Laem-Singh virus (LSNV) (Sritunyalucksana et al. 2006). The unusually retarded growth and wide variation in size, without abnormal 
mortality (which is similar to MSGS in Thailand), have also been reported from East Africa (Anantasomboon et al. 2006). Though such disease problems have been frequently observed in hatcheries and growout systems in India, no studies have been conducted to determine the possible association of viral/bacterial pathogens. Here, we present a first report of the occurrence of LSNV in cultured shrimp ( $P$. monodon) from the Indian coast.

\section{MATERIALS AND METHODS}

Diseased samples of tiger shrimp Penaeus monodon were collected randomly from shrimp farms in Kundapura (Karnataka) along the southern west coast and in Kakinada and Amalapuram (Andhra Pradesh) along the southern east coast of India. Post larvae (PL) were collected from different hatcheries along the southeastern and southwestern coasts of India. The PL were preserved in RNAlater (Ambion) and brought to the laboratory. Juvenile and adult shrimp samples were processed immediately upon collection for extraction of RNA.

Extraction of viral DNA. Approximately $100 \mathrm{mg}$ of hepatopancreas, gills and pleopods were taken separately from each sample, and DNA was extracted using the method described by Otta et al. (1999). DNA extracted from the hepatopancreas was used for the detection of both HPV and MBV by PCR, while the DNA from gills and pleopods was used for detection of WSSV. In the case of PL, more than 30 individuals were taken for DNA extraction.

Total RNA was extracted from samples using TRIzol LS reagent (Invitrogen) according to the manufacturer's instructions. Briefly, $750 \mu \mathrm{l}$ of TRIzol reagent was added to the tissue (hepatopancreas/PL) and homogenized. After incubating for $5 \mathrm{~min}$, it was centrifuged at $12000 \times g$ for $15 \mathrm{~min}$ at $2^{\circ} \mathrm{C}$. RNA was precipitated from the aqueous phase with isopropanol, washed with $75 \%$ ethanol and dissolved in $50 \mu$ of diethylpyrocarbonate treated water. This was stored at $-80^{\circ} \mathrm{C}$.

Polymerase chain reaction. Nested PCR was performed for detection of WSSV, MBV and HPV using primers and thermocycling conditions previously described for WSSV (Hossain et al. 2001), MBV (Belcher \& Young 1998, Otta et al. 2003) and HPV (Phromjai et al. 2002, Umesha et al. 2006). All the amplification reactions were carried out in a $30 \mu \mathrm{l}$ reaction mixture consisting of a $1 \mathrm{X}$ assay buffer (Bangalore Genei), $10 \mathrm{pmol}$ of each forward and reverse primer, $200 \mu \mathrm{M}$ of each of 4 deoxyribonucleotide triphosphates (dNTPs), $1 \mathrm{U}$ of Taq DNA polymerase (Bangalore Genei), and $2 \mu$ of DNA extract as template. All PCR reactions were performed in a PTC 100 thermocycler (MJ Research). The amplified PCR products were electrophoresed in a $1.5 \%$ agarose gel, stained with ethidium bromide $\left(0.5 \mu \mathrm{g} \mathrm{ml}^{-1}\right)$ and photographed using a gel documentation system (HeroLab).

Reverse transciption-PCR (RT-PCR). One pair of primers specific to LSNV (described by Sritunyalucksana et al. 2006) was used for amplification of LSNV RNA, yielding a product of $200 \mathrm{bp}$. For nested PCR, primers LSNVnF 5' GCG CAA GAG TTC TCA GGC TT 3 ' and LSNVnR 5'ATC ACC GCA GGC TAA TAT AG $3^{\prime}$ internal to the $200 \mathrm{bp}$ fragment were designed from the sequence (GenBank Accession No. DQ127905) to yield an amplicon size of $140 \mathrm{bp}$. Reactions were performed in $30 \mu \mathrm{l}$ RT-PCR buffer containing $10 \mathrm{pmol}$ of each primer and $2 \mu \mathrm{l}$ of RNA template. The thermocycling conditions consisted of RT at $42^{\circ} \mathrm{C}$ for $1 \mathrm{~h}$, denaturation at $94^{\circ} \mathrm{C}$ for $5 \mathrm{~min}$ followed by 35 cycles of denaturation at $94^{\circ} \mathrm{C}$ for $1 \mathrm{~min}$, annealing at $60^{\circ} \mathrm{C}$ for $1 \mathrm{~min}$, and elongation at $72^{\circ} \mathrm{C}$ for $1 \mathrm{~min}$, ending with an additional elongation step of $10 \mathrm{~min}$ at $72^{\circ} \mathrm{C}$. The RT-PCR products were then analyzed by electrophoresis on a $2 \%$ agarose gel. A cloned LSNV fragment (kindly provided by T. W. Flegel, Thailand) was used as the positive control.

\section{RESULTS AND DISCUSSION}

Of the 56 samples analyzed in this study (Table 1), 28 were positive for WSSV, 14 for MBV and 12 for HPV. All these samples were also analyzed by RT-PCR for the detection of LSNV, and 3 were found to be positive (Fig. 1). Interestingly, none of the swollen hindgut syndrome postlarval samples was positive for LSNV by

Table 1. Penaeus monodon. Numbers of samples analyzed for white spot syndrome virus (WSSV), monodon baculovirus (MBV), hepatopancreatic parvovirus (HPV), and Laem-Singh virus (LSNV) which displayed signs of loose shell syndrome (LSS), swollen hindgut syndrome (SHG), or were normal or putatively normal

\begin{tabular}{|c|c|}
\hline Sample details & of samples \\
\hline $\begin{array}{l}\text { Samples with loose shell syndrome } \\
\left(\text { Kundapura }^{\mathrm{a}}\right)\end{array}$ & 4 \\
\hline $\begin{array}{l}\text { Samples with swollen hindgut syndrome } \\
\text { (post larvae) (Kakinada }{ }^{b} \text { ) }\end{array}$ & 13 \\
\hline Samples of putatively normal post-larval stage & 21 \\
\hline $\begin{array}{l}\text { Samples with swollen hindgut syndrome } \\
\text { (Kundapura) }\end{array}$ & 5 \\
\hline Normal adult samples & 13 \\
\hline $\begin{array}{l}{ }^{\text {a }} \text { Southern west coast of India } \\
\text { bouthern east coast of India }\end{array}$ & \\
\hline
\end{tabular}




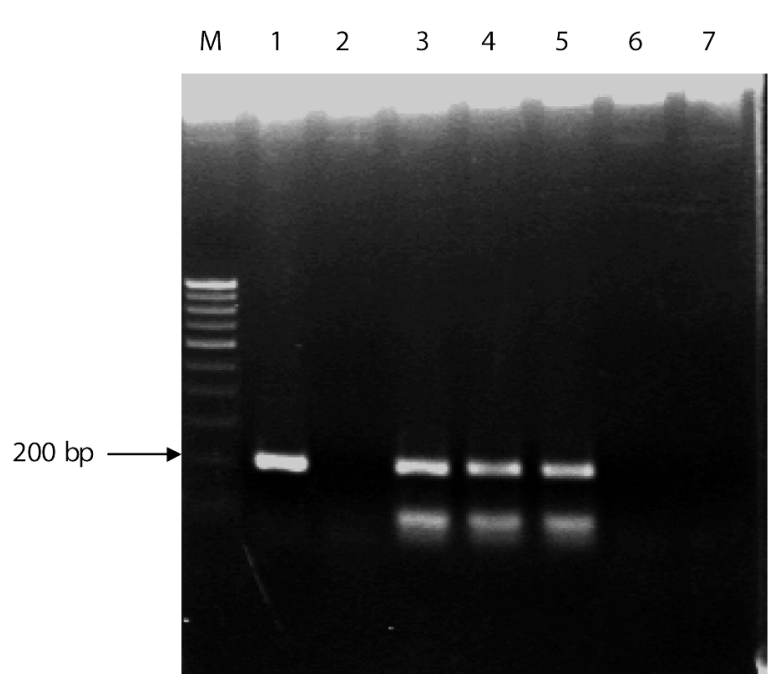

Fig. 1. Penaeus monodon. First step RT-PCR for detection of LSNV. M: 100 bp DNA ladder Plus (Gene Ruler TM genetix) . Lane 1: Positive control; Lane 2: Negative control; Lanes 3 - 5: samples with LSS positive for LSNV; Lane 6: Normal adult shrimp sample; Lane 7: Normal postlarvae

RT-PCR. All 3 LSNV-positive samples were confirmed by sequencing the PCR products. BLAST (Altschul et al. 1997) analysis of the sequences revealed $98 \%$ homology (EF593037) with the sequences of LSNV reported by Sritunyalucksana et al. (2006). To our knowledge, this is the first report of LSNV from India.

All 3 samples positive for LSNV were adult shrimp showing signs of 'loose shell syndrome' (LSS). LSSaffected shrimp have hard or leathery shells (that are not soft), and shrunken tail meat, so that there is a gap between the shell and the muscle tissue (causing the 'loose shell'). They also reject feed and may have swollen hindguts that contain a whitish fluid. Moribund specimens exhibit bacterial and fungal infections and exterior algal fouling. The infected shrimps move to the pond margin and finally die. Studies conducted so far have not conclusively determined the etiological agent for this syndrome. The presence of LSNV in both normal and MSGS shrimp has been reported previously (Sritunyalucksana et al. 2006).

Of the 3 shrimp samples positive for LSNV, 2 were also positive for WSSV and MBV, and within these 2 samples, 1 was also infected with HPV. Previous studies have revealed multiple infections in growthretarded Penaeus monodon cultivated in Thailand (Chayaburakul et al. 2004). According to these studies, HPV infection was a contributing factor, but not the overriding factor responsible for MSGS, even though P. monodon infected with HPV shows reduced growth (Flegel et al. 1999). Multiple viral infections were also reported in postlarval samples from hatcheries (Manivannan et al. 2002) and from adult shrimp (Umesha et al. 2006). In the present study, we could not relate the presence of LSNV to LSS, even though the 3 samples positive for LSNV showed symptoms of LSS. More studies are needed to understand the impact of LSNV on shrimp health and growth.

Acknowledgements. Financial support from the Department of Biotechnology, Government of India through the 'Programme Support in Fisheries Biotechnology' is gratefully acknowledged.

\section{LITERATURE CITED}

Altschul SF, Madden TL, Schaffer AA, Zhang J, Zhang Z, Miller W, Lipman DJ (1997) Gapped BLAST and PSIBLAST: a new generation of protein database search programs. Nucleic Acids Res 25:3389-3402

Anantasomboon G, Sriurairatana S, Flegel TW, Withyachumnarnkul B (2006) Unique lesions and viral like particles found in growth retarded black tiger shrimp Penaeus monodon from East Africa. Aquaculture 253:197-203

Belcher CR, Young CR (1998) Colourimetric PCR-based detection of monodon baculovirus in whole Penaeus monodon postlarvae. J Virol Methods 74:21-29

Chantanachookin C, Boonyaratpalin S, Kasornchandra J, Direkbusarakom S, Ekpanithanpong U, Supamataya K, Sriurairatana S, Flegel TW (1993) Histology and ultrastructure reveal a new granulosis-like virus in Penaeus monodon affected by yellow-head disease. Dis Aquat Org 17:145-157

Chayaburakul K, Nash G, Pratanpipat P, Sriurairatana S, Withyachumnarnkul B (2004) Multiple pathogens found in growth retarded black tiger shrimp Penaeus monodon cultivated in Thailand. Dis Aquat Org 60:89-96

Flegel TW, Thamavit V, Pasharawipas T, Alday-Sanz V (1999) Statistical correlation between severity of hepatopancreatic parvovirus (HPV) infection and stunting of farmed black tiger shrimp (Penaeus monodon). Aquaculture 174:197-206

Hossain MS, Chakraborty A, Joseph B, Otta SK, Karunasagar I, Karunasagar I (2001) Detection of new host for whitespot syndrome virus of shrimp using nested polymerase chain reaction. Aquaculture 198:1-11

Lavilla-Pitogo CR, Paner MG, Travina RD (2002) Swollen hindgut syndrome (SHG) in hatchery reared Penaeus monodon post larvae. In: Lavilla-Pitogo CR, Cruz-Lacierda ER (eds) Diseases in Asian aquaculture IV. Fish Health Section, Asian Fisheries Society, Manila, p 151-158

Lightner DV (1988) Diseases of cultured penaeid shrimp and prawns. In: Sinderman CJ, Lightner DV (eds) Disease diagnosis and control in North American marine aquaculture. Elsevier, Amsterdam, p 8-133

Lightner DV (1993) Diseases of cultured penaeid shrimp. In: McVey JP (ed) CRC handbook of mariculture, 2nd edn, Vol 1. Crustacean aquaculture. CRC Press, Boca Raton, FL, p 393-486

Lightner DV (1996) A handbook of shrimp pathology and diagnostic procedures for diseases of cultured penaeid shrimp. World Aquaculture Society, Baton Rouge, LA

Manivannan S, Otta SK, Karunasagar I, Karunasagar I (2002) Multiple viral infection in Penaeus monodon shrimp postlarvae in an Indian hatchery. Dis Aquat Org 48:233-236

Mayavu P, Purushothaman A, Kathiresan K (2003) Histology of loose-shell affected Penaeus monodon. Curr Sci 85:1629-1634 
Otta SK, Shubha G, Joseph B, Chakraborty A, Karunasagar I, Karunasagar I (1999) Polymerase chain reaction (PCR) detection of white spot syndrome virus (WSSV) in cultured and wild crustaceans in India. Dis Aquat Org 38:67-70

Otta SK, Karunasagar I, Karunasagar I (2003) Detection of monodon baculovirus (MBV) and whitespot syndrome virus (WSSV) in apparently healthy Penaeus monodon postlarvae from India by polymerase chain reaction. Aquaculture 220:59-67

Phromjai J, Boonsaeng V, Withyachumnarnkul B, Flegel TW (2002) Detection of hepatopancreatic parvovirus in Thai

Editorial responsibility: Timothy Flegel,

Bangkok, Thailand shrimp Penaeus monodon by in situ hybridization, dot blot hybridization and PCR amplification. Dis Aquat Org 51:227-232

Sritunyalucksana K, Apisawetakan S, Boon-nat A, Withyachumnarnkul B, Flegel TW (2006) A new RNA virus found in black tiger-shrimp Penaeus monodon from Thailand. Virus Res 118:31-38

Umesha KR, Bob Kennedy MD, Manja Naik B, Venugopal MN, Karunasagar I, Karunasagar I (2006) High prevalence of dual and triple viral infection in black tiger shrimp ponds in India. Aquaculture 258:91-96

Submitted: March 28, 2007; Accepted: June 5, 2007

Proofs received from author(s): July 31, 2007 